\title{
Development of an Android-based Computer Based Test (CBT) In Middle School
}

\author{
Nurhikmah H $^{1 *}$, Hamsu Abdul Gani ${ }^{2}$, Muh. Putra Pratama ${ }^{3}$, Hengki Wijaya ${ }^{4}$ (D) \\ 1,2,3,4 Educational Technology Study Program, Universitas Negeri Makassar, Makasar, Indonesid
}

\section{A R T I CLE I N F O}

Article history:

Received April 05, 2021

Revised April 10, 2021

Accepted May 04, 2021

Available online May 25, 2021

\section{Kata Kunci:}

Computer-Based Test,

Android, Online,

Pembelajaran, Evaluasi

Keywords:

Computer-Based Test,

Android, Online, Learning,

evaluation

\begin{abstract}
A B S T R A K
Guru masih menggunakan proses evaluasi semi konvensional yaitu proses ujian dilakukan dengan memanfaatkan media sosial untuk mengirimkan hasil ujian peserta didik yang dikerjakan manual pada kertas. Proses evaluasi seperti ini kurang efektif dan efisien, baik dari segi waktu, metode yang digunakan, dan proses pemeriksaan hasil ujian yang membutuhkan waktu yang cukup lama dan pemeriksaan yang tidak akurat. Penelitian ini bertujuan untuk mengembangkan Computer Based Test berbasis Android. Metode penelitian ini Research and Development yang difokuskan untuk mengembangkan Computer Based Test berbasis smartphone khususnya android. Model pengembangan yang digunakan mengacu pada model pengembangan Alessi and Trollip. Subjek penelitian keseluruhan 30 siswa dan 1 guru mata pelajaran matematika. Instrumen yang digunakan untuk mengumpulkan data adalah kuesioner. Teknik pengumpulan data yang digunakan adalah observasi, wawancara, angket atau angket, tes, dan dokumentasi. Teknik yang digunakan menganalisis data yaitu analisis deskriptif kualitatif dan kuantitatif. Hasil penelitian yaitu hasil validasi oleh ahli materi diperoleh skor rata-rata 3,7 (sangat valid) dan oleh ahli media diperoleh skor rata-rata 3,8 (sangat valid) sehingga Computer Based Test dapat diujicobakan dilapangan untuk mengetahui kepraktisan dimana tingkat kepraktisan memenuhi kriteria dengan hasil sangat prkatis. Hal ini berarti dapat dinyatakan bahwa Computer Based Test berbasis Android ini sangat praktis dalam proses evaluasi/ujian pada mata pelajaran matematika. Berdasarkan hasil uji kelayakan Computer Based Test tersebut maka dapat disimpulkan bahwa penggunaan Computer Based Test layak untuk digunakan sebagai media evaluasi pembelajaran pada mata pelajaran matematika.
\end{abstract}

\section{A B S T R A C T}

Teachers still use a semi-conventional evaluation process. Namely, the exam process is carried out by utilizing social media to send students' exam results manually on paper. This kind of evaluation process is less effective and efficient, both in terms of time, the method used and examining exam results which takes a long time and is inaccurate. This study aims to develop a Computer Based Test based on Android. This research method is Research and Development, which is focused on developing a Computer Based Test based on smartphones, especially Android. The development model used refers to the Alessi and Trollip development model. The research subjects were 30 students and 1 mathematics teacher. The instrument used to collect data is a questionnaire. Data collection techniques used are observation, interviews, questionnaires or questionnaires, tests, and documentation. The technique used to analyze the data is descriptive qualitative and quantitative analysis. The results of the study were the results of validation by material experts obtained an average score of 3.7 (very valid). By media, experts obtained an average score of 3.8 (very valid) so that the Computer Based Test could be tested in the field to determine the practicality where the practicality level met criteria with efficient results. This means that it can be stated that the Android-based Computer Based Test is efficient in the evaluation/exam process on mathematics subjects. Based on the feasibility test of the Computer Based Test, it can be concluded that the use of the Computer Based Test is feasible to be used as a medium for evaluating learning in mathematics subjects.

This is an open access article under the $\underline{C C B Y-S A}$ license.

Copyright (C) 2021 by Author. Published by Universitas Pendidikan Ganesha.

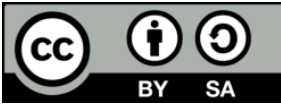

\section{INTRODUCTION}

Science and technology are developing rapidly (Bergdahl, Nouri, \& Fors, 2020; Shohel \& Kirkwood, 2012). Smartphone devices have dominated people's daily lives with the various facilities provided. Nowadays, smartphones are used as a tool for communication, technology, and development and have made smartphones already used as a medium in the teaching and learning process (Handayani, Elvinawati, Isnaeni, \& Alperi, 2021; Q. Liu, Huang, \& Zhou, 2020; Suryanda, Sartono, \& Sa'diyah, 2019). Educators and students can directly experience the positive things in optimizing smartphones in education, namely supporting the development of 
education (Irni, Sumarni, \& Saraswati, 2017; Sunismi, 2015). For example, using smartphones, students and teachers have easy access to knowledge and broader access. With advances in technology to support education like this, it can make it easier for anyone, both students and educators, to increase knowledge indefinitely (Cecep, Mutaqin, \& Pamungkas, 2019; Chen \& Tsai, 2021; Rorita, Ulfa, \& Wedi, 2018).

Based on the results of observations made in October 2019 at SMP Negeri 19 Makassar, the evaluation of student learning outcomes still uses the Paper Based Test (PBT) system for daily tests or final school exams. The exam model used is still conventional exams or still uses paper media to implement the exam. They are looking at various aspects in applying paper-based examinations (PBT) such as time effectiveness, the objectivity of assessment, reducing fraud, scoring, and minimizing paper expenditure/use. The test aids for the PBT testing model are paper and pencil. Paper is used as a medium for displaying the items, and pencils are used to respond to the answer. Unlike the CBT test model, it requires only a smartphone device connected to the internet network. The use of smartphones in evaluating learning outcomes has not been fully utilized by educators, especially in examinations on mathematics subjects. Implementing android-based exams is expected to attract students' interest and make it easier for the education personnel process to examine exam results by obtaining accurate results from the exam application used. On the other hand, using android-based exam applications also reduces paper usage in the Paper Based Test (PBT) exam process. The interviews with the SMP Negeri 19 Makassar principal on January 18, 2020; for now, the application of a new computer-based exam is at the national exam stage. The application of computer-based exams still adapts to computer devices in schools. Seeing the development of technology among students, especially in the use of smartphones, which is relatively high, it's just that educators have not fully utilized its service in the learning process or the implementation of exams. Another problem faced by the teacher is correcting student answers, which takes a long time so that the student's assessment cannot know the results. Correction of student answers that is done manually also has the potential for human error.

In line with the interviews with the principal, the mathematics subject teacher revealed that the learning process during the Covid-19 pandemic. It made everything full online, including evaluating learning outcomes. Teachers were often burdened by administrative tasks that were very time-consuming, so tools were needed for effective and practical evaluation. This causes the process of evaluating subject learning to be usually not achieved or not following expectations at the end of learning. Many of the students have evaluation results that are less related to the subject matter. Currently, the evaluation process is applied semi-conventional evaluation where the exam process uses the WhatsApp group chat. The teacher carries out the distribution of questions through groups, and students will send back their exam results. Seeing that the exam conditions have not been fully maximized, on the other hand, the high level of smartphone ownership among students makes it easier for teachers to learn and the evaluation process. CBT, or the use of computers to provide tests/evaluations for students, make quality improvement in the evaluation process more effective and efficient (Chua \& Don, 2013; Mastroleo, Humm, Williams, \& Kiluk, 2020; Novrianti, 2014).

Along with its development in education, smartphones have been used in the teaching and learning process and in examining/evaluating learning outcomes (C. Liu et al., 2021; Park, Choi, Kim, \& Lee, 2020; Sophonhiranrak, 2021). It is necessary to have an evaluation or assessment to determine how students understand the material given by the educator/teacher (Devraj, Colyott, \& Cain, 2021; Peralbo-Uzquiano et al., 2020). The era of the Covid-19 pandemic has had many impacts, especially in the field of education-online learning policy for all students due to social restrictions or learning from home (Jogezai et al., 2021; Sari, Sinaga, Hernani, \& Solfarina, 2020). The online learning process is enforced at all levels of education, giving teachers can use the internet, both in the teaching and learning process or examining/evaluating student learning outcomes (Abidah, Hidaayatullaah, Simamora, Fehabutar, \& Mutakinati, 2020; Intania, 2020). Teachers are required to make innovations in the learning process, especially in the evaluation process of students (Jogezai et al., 2021; Sari, Sinaga, Hernani, \& Solfarina., 2020). CBT is a solution for mass evaluation using computers. Information and communication technology is utilized in education, including computer-based assessments using computer tests (Chua \& Don, 2013; Hermes, Albers, Böhnke, \& Huelmann, 2019). Android-based Computer Based Test (CBT) is a test that is carried out using an android. It is assisted by a computer system where the test takers are no longer bothered with computers or laptops with a high enough price because, with an android, it is inevitable that the test takers have them. CBT is defined as a series of computer-based tests or assessments involving either a standalone computer or connected to an internet network (Mastroleo et al., 2020). Computer Based Test (CBT) is an automatic assessment system and is considered to be effective because it can be easily operated by anyone (Bolls \& Castell, 2013; Lia M. Daniels \& Gierl, 2017).

Several essential aspects that can be considered in developing this Android-based CBT are practical, economical, and easy to carry out the exam process (Mastroleo et al., 2020; Papamitsiou \& Economides, 2017). Practical value, in principle, provides convenience in every procedure carried out by utilizing ICT. The economic value, in this case, is the implementation of tests that make use of ICT more cheaply and efficiently (Kim, Lee, \& Kwak, 2020; Kristinawati, Susilo, \& Gofur, 2018; Siddiq et al., 2019). The tendency to use paper 
materials can be reduced, reducing the cost of purchasing paper and other materials. The computer-based test can be used in an environment that can be supervised or not supervised by an exam supervisor and can allow students to check their progress through self-assessment (Chua \& Don, 2013; Prisacari \& Danielson, 2017). Electronic examinations (e-Examination for short systems) involve conducting tests via the web or intranet and reducing the large proportion of workloads on examinations, training, assessments, and reviews. There are many benefits to using computers in education, especially in the application of exams (Ayo, Akinyemi, Adebiyi, \& Ekong, 2017). There are many conveniences obtained during exams using computers, such as automatic assessments, get feedback quickly, and the questions can be saved in a question bank (Hill, Horswill, Whiting, \& Watson, 2019). Computer applications in learning continue to develop, in tune with the development of information technology in improving the quality of learning. At present, the conventional paper-based test (paper-based test) has shifted towards computerization or what is commonly called the Computer Based Test (CBT) (Novrianti, 2014; Valle, Støen, Sæther, \& Sæther, 2019). Android-based CBT can help all of these activities more easily manage systematic so that activities are more focused even though they do not meet faceto-face, but through online learning. research conducted in America, computer-based exams are more credible and able to provide facilities comparable to paper-based exams (Mastroleo et al., 2020; Seo \& De Jong, 2015).

The findings of previous studies also state that computer based tests (CBT) can make it easier for teachers to assess students (Novrianti, 2014; Prisacari \& Danielson, 2017). In this study, researchers are interested in developing a Computer Based Test (CBT) as a medium that can help teachers evaluate student learning outcomes. The purpose of this study is to develop an Android-based Computer Based Test (CBT) in Junior High Schools. The computer-based test developed based on android, the selection of android in CBT development is based on the level of smartphone ownership among students. This CBT run must be connected to the internet, either during the test or during installation on android. Working on exam questions on the CBT application can be done anywhere based on the schedule set by the teacher, and the test results will appear when the exam is finished.

\section{METHOD}

Research and Development Methods are research methods used to produce specific products and test the resulting products' effectiveness. This research is a research and development $(\mathrm{RnD})$ which aims to develop CBT applications for junior high school students in Makassar. This study's development model adopted the development model of Stephen M. Alessi and Stanley R. Trollip, namely through planning, design, and development (Alessi \& Trollip, 2001). Alessi and Trollip's development model has components consisting of planning, design and development steps (planning, design \& development) and attributes that are always present in every stage. These attribute components include standards, ongoing evaluation, and project management, which are complementary and are considered in developing products. The reason for choosing the Alessi and Trollip development model is that this development model consists of relatively simple stages (3 stages) but includes sub-components described in more detail. The sub-components of the model are explained explicitly to guide the developer in producing an effective product. The attributes used in Alessi and Trollip's model can also assist product development to be completed quickly but within management and quality standards. The Alessi and Trollip's development model shown in Figure 1.

This development research took the subject of research in class IX SMPN 19 Makassar with 30 students, which were divided into 14 male students and 16 female students. Class IX was chosen as the subject so that students get used to doing computer-assisted or android-assisted test/exam questions so that when they face computer-based national exams, students will be familiar with, in other words, students have indirectly tried out before facing the National Examination. The instrument used to collect data is a questionnaire. Data collection techniques used in the development of CBT are observation, interviews, questionnaires or questionnaires, tests, and documentation. Interviews in this study were conducted with the principal of SMP Negeri 19 Makassar. In this interview stage, the researcher met directly with the principal as the leader of SMP Negeri 19 Makassar and the mathematics subject teacher who was the teaching teacher to find out what material was taught in grade IX. From the results of the interviews, the researcher can conclude that the development of suitable CBT in SMP Negeri 19 Makassar, especially in mathematics subjects. The questionnaire in CBT research and development is given to the validator to assess the development product. In this study, the first questionnaire for the validator and the second one for students. The questionnaire given was in the form of a validation questionnaire and a student response questionnaire. This validation questionnaire is submitted to media expert lecturers and material experts. This questionnaire was given to get input from media experts and content experts to evaluate and develop an Android-based computer-based test (CBT). Meanwhile, a student questionnaire was given after the product was applied to determine the level of attractiveness and practicality of the Computer Based Test (CBT) that the researcher had developed. The test is used to determine the extent to which students understand the subject matter. In this study, researchers used multiple-choice tests presented in a 
software program. The techniques used to analyze the research data are qualitative descriptive analysis, quantitative, and inferential statistics. This technique is a qualitative descriptive analysis used to process data from the results of trials from experts based on the input provided. The quantitative descriptive analysis technique is used to process data from trials from experts based on the assessment given. Product effectiveness tests are also carried out to test the feasibility and practicality of the developed Computer Based Test.

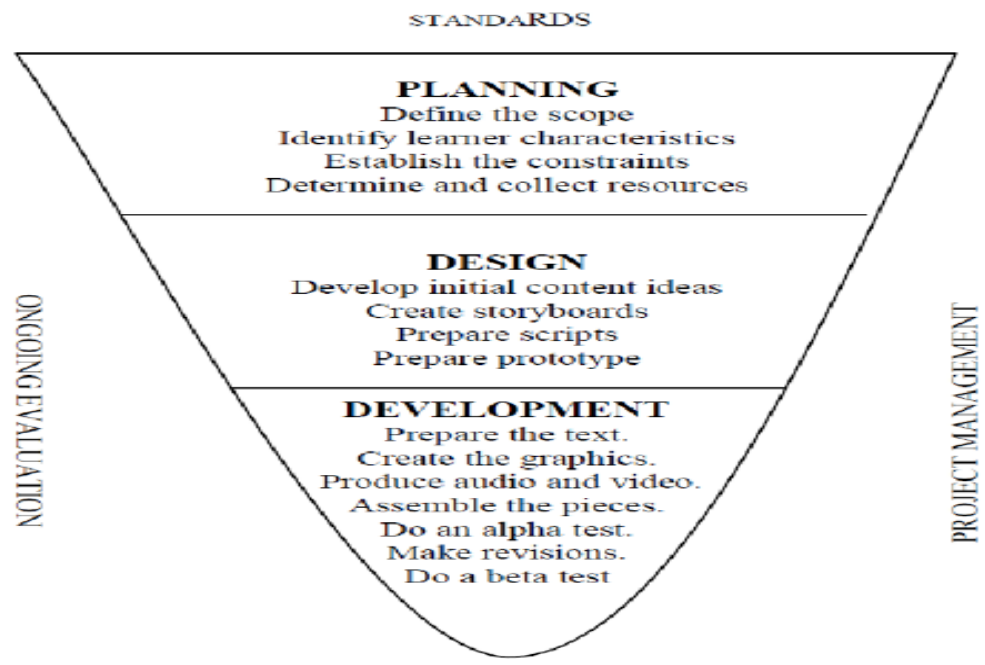

Figure 1. Model of Instructional Design (Alessi \& Trollip, 2001)

\section{RESULT AND DISCUSSION}

\section{Result}

Selection of subjects in developing Computer Based Test (CBT) is by considering some of the results from interviews with school principals and subject teachers at SMP Negeri 19 Makassar. The interview results obtained some information that supported the selection of subjects to be developed in this Computer Based Test (CBT). Based on the interview results, the researchers raised mathematics as material to be developed in computer-based exams or Computer Based Test (CBT). Students will work more thoroughly on questions online than offline. According to the grade IX mathematics subject teacher, it was stated that the future of smartphones, especially Android, had not been fully utilized. On the other hand, the level of smartphone usage among students was very high.

The first step is planning. At this stage, they are identifying the characteristics of students who aim for the development of Computer Based Test (CBT) to be right on target and by the needs of users, in this case, students and educators. Based on the identification results of students, there is a description of the characteristics of class IX students of SMP Negeri 19 Makassar, namely: 1) Junior high school students have an average age of 12-15 years. At this level, motivation increases when using digital media. Students remember what they see more than what they hear, have different speeds in understanding subject matter, and imagine trying things new, 2) All students have a smartphone device, 3) Students actively use smartphones to do school work, 4) Students search for subject matter using a smartphone, 5) Students are enthusiastic about installing an android-based exam application. Based on these characteristics, students need to be facilitated by media in learning, especially in learning evaluation. One of them is using Computer Based Test (CBT) in doing exam questions. Evaluation using a Computer Based Test (CBT) is used in an android application which looks not much different from a computer-based Computer Based Test (CBT).

The process in this stage is the preparation of a planning document, consisting of material manuscripts, test documents, and test assessments. The need for material scripts includes a Learning Implementation Plan (LIP) obtained from mathematics subject teachers and question texts. The question manuscript consists of a question lattice script which consists of the question itself and the answer key. Simultaneously, the assessment instrument is in the form of a grid or questionnaire for material experts, media experts and student responses. After composing the math teacher's questions, the questions are first validated by material experts before the questions are input into the Computer Based Test (CBT). The selection of questions and materials was consulted with the mathematics subject teacher. At this stage, supporting resources were collected in developing a Computer Based Test (CBT) in software and supporting facilities and infrastructure. After the application design 
has been completed, inputting some of the pillars will be tested on students. Further identification relates to the supporting facilities and infrastructure needed to run the developed Computer Based Test (CBT). This Computer Based Test (CBT) will be in digital form, read on an android application with (.apk) file format. Based on interviews with subject teachers, the level of smartphone use among students is very high; almost all students already have smartphones, especially Android. The following process deals with the material content or questions that will be used as evaluation material. The material/questions that the subject teacher evaluates. A material expert validates the questions before being entered into the Computer Based Test (CBT) application. Determine the boundaries as information on the use of the media to be developed. The limits specified are the minimum hardware, smartphone and software that will be used.

The second stage is design. The process in this stage is that all ideas are developed. The idea is about the appearance, programming and form of a computer-based test (CBT) that can present text and image content. Computer Based Test (CBT) can load this content in the form of applications that can be used on smartphone devices, especially Android. At this stage, what is done is to analyze the material, practise questions, and sample questions obtained from the teacher by the lesson plan's learning objectives. The next stage is compiling questions based on the material by the results to be achieved. At this stage, a program planning design is made in the form of a flowchart and storyboard. A flowchart is a computer-based test (CBT) development flow that will be developed. Furthermore, the preparation of this flowchart is used as the basis for making storyboards. Storyboards are created to compile product designs, be it appearance, colours, buttons, text, etc. The flowchart of computer-based test (CBT) shown in Figure 2.

The flowchart explains the flow when starting the Android-based exam application program. After the user/student has successfully logged in by entering a username and password, they will be redirected to the class join page and choose the exam to be taken. Then students will get a display of questions after selecting the exam; by pressing the start button. The exam can be started, and the time is reduced until the exam is finished. After finishing working on the questions, users/students can see the test results by clicking the "show results" link. After getting the program's flow to be created, the next step is to determine the display design in the form of a storyboard. The storyboard is a brief descriptive description of the flow of the Android-based Computer Based Test (CBT) application from start to finish. A storyboard is a series of manual drawings created to describe a story and is used to describe a multimedia object and its behavior (Sutopo, 2003). As shown in Figure 3, the initial display when creating the application will appear on the login screen. The login page is a page that will verify the user and password of students/teachers who will access the application. After successfully logging in, it will be redirected to the dashboard page. The user can see several tools such as the exam list and change user/user data before entering the exam view on the dashboard page. Students and teachers can change user names, change passwords, phone number, and other data in the user data menu. Student and teacher dashboard menus have different access or views. The teacher view has more tools/menus for creating exams, adding questions, exam time, etc. On the Student view only, it displays Change user data and sees a list of exams. The teacher's exam list will appear automatically on the student display, as shown in Figure 4.

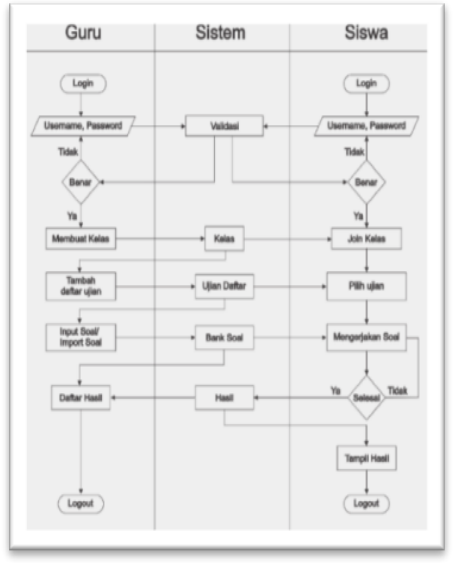

Figure 2. Flowchart Computer Based Test (CBT)

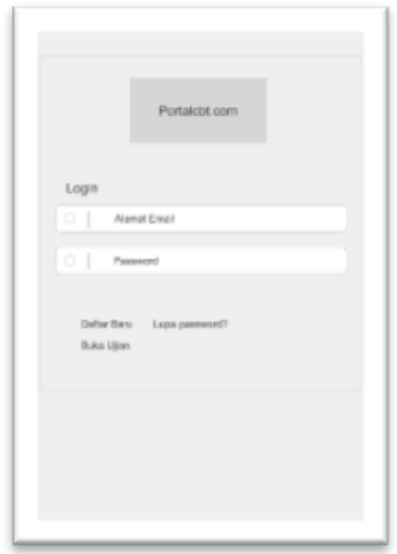

Figure 3. Login PageDesign

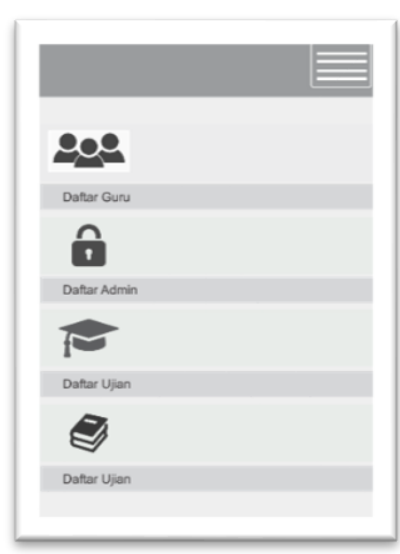

Figure 4. Dashboard Page Design

The third stage is development. The process in this development stage includes the development of content in the Computer Based Test (CBT), which consists of text, images, practice questions, etc., to make it easy to read on Android or in the form of an application to make it easy to read on Android. The Computer Based Test (CBT) component developed is the same as the computer-based exam component in general, which consists of the login page, dashboard page, user list page, exam list page, exam result page, question list page 
(question bank), change data page users, and the student exam results page. Exams are presented in mathematics subjects with the material of multiplication, division, and fraction. The type of exam given is in the form of a multiple-choice exam with an estimated time and passing standard that the application has determined. The Computer Based Test (CBT) login page is a user verification page for accessing the application. To log into the application, the user or user first creates an account or has access to use features and work on evaluation questions. The cover page display can be seen in Figure 4. The dashboard page is the main page that will appear after the user or user has successfully logged in to the Computer Based Test (CBT) application. This page displays access to the user page, the exam list page, the page, the list of questions (question bank), and user data changes. Students' access is only to view the list of exams and change user data and see the results of the completed exams to find out the scores achieved. The output displays the answer keys as an evaluation material for how far they have been achieved. The dashboard page can be seen in Figure 6.

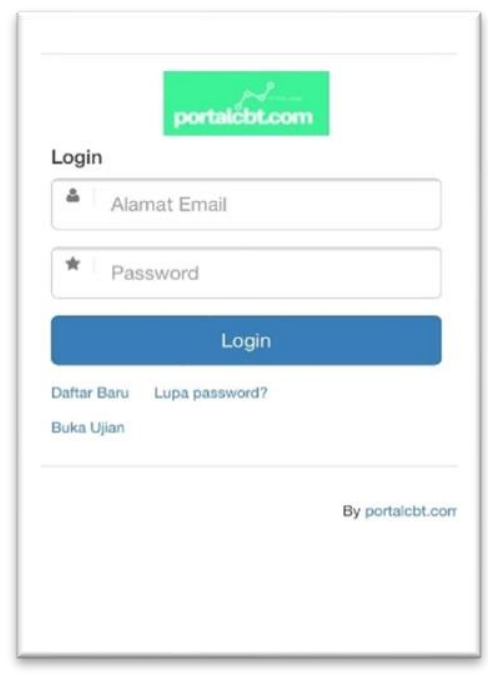

Figure 5. Computer Based Test (CBT) login page

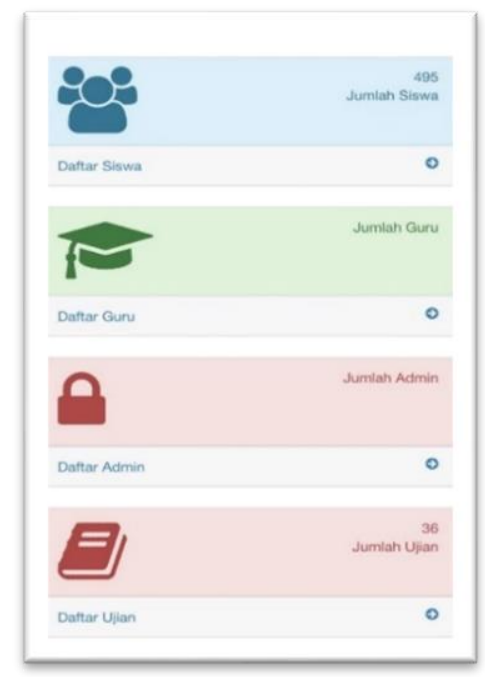

Figure 6. Dashboard Page of Computer Based Test $(\mathrm{CBT})$

More access is made for educators, such as updating student data, adding questions, adding subjects, adding exam categories, and viewing student exam results. The Computer Based Test (CBT) component was developed based on a needs analysis, and a test structure was made starting from adding users to question input and displaying the answer key in the test results. Composition or design of Computer Based Test (CBT) applications. One of the main criteria for determining whether a learning media is suitable for use or not is the validation result. Expert validation involves two expert validators consisting of one material expert validator and a media expert. In this process, besides getting an assessment from the validator, they also get comments and suggestions. Comments and recommendations from the validator are used as suggestions for revising the media being developed. Based on the validator's assessment on the material/display content aspect, an average score of 3.6 indicates that this aspect is in a very valid category. In the construction aspect, an average score of 3.6 is obtained, which suggests that this aspect is in the very valid category. In the language aspect, an average score of 4 is obtained, which indicates that this aspect is in the very valid category. The average score of validation score on the material is 3.7, which shows that which media is in a very valid category. 1) Pay attention and readjust the questions that have been made regarding circles and distances, 2) The language in the questions is made more explicit and easier to understand.

Based on the validator's assessment of the physical aspect, an average score of 4 is obtained, which indicates that this aspect is in a very valid category. In the aspect of font selection's appropriateness, an average score of 3.6 indicates that this aspect is in the very category. Valid, in the evaluation aspect, an average score of 3.6 is obtained, which suggests that this aspect is in the very valid category. In the display aspect, an average score of 4 is obtained, which indicates that in this aspect. It is in the very valid category, and in the linguistic aspect, received an average score of 3.6, which indicates that this aspect is in the very valid category so that the average score of validation on the media is 3.8 , which indicates that the media is in a very valid category. As for what the media validator suggests, that is what the media validator suggests, namely adjusting the font according to the application's appearance to make it look more proportional. Results indicated that the CBT mode is more reliable in terms of internal and external validity. The CBT significantly reduced testing time and developed stronger self-efficacy, intrinsic and social testing motivation in the participants. CBT exam results are reliable in 
terms of validity and reduce testing time, thereby increasing the test takers' motivation. After analyzing the results obtained from the two validators, tests were carried out on the teacher and the subject to get data about the assessment of the development of Android-based CBT. At this stage, 1 Mathematics teacher who teaches at SMP Negeri 19 Makassar and 30 students consisting of 14 male students and 16 female students in class IX SMP Negeri 19 Makassar is involved. The CBT system is tested in one class in vocational high schools in Indonesia using a system eligibility instrument adapted from the Technology Acceptance Model (TAM) to determine the CBT system's feasibility level in its perceived usefulness and ease of use.

Figure 7 and Figure 8 show that the response of the class IX mathematics teacher at SMP Negeri 19 Makassar after carrying out learning activities obtained an average score of 3.31 which means that the teacher's response is in the category of strongly agree. So, it can be concluded that the student's response strongly agrees with using the Computer Based Test (CBT) in evaluating learning outcomes. Based on the results of the development with consideration, where the Computer Based Test (CBT) is developed based on the needs in evaluating learning outcomes so that it can benefit schools, teachers and students. Based on the development results through the content validation stage carried out by media experts and material experts revising the design results and providing an assessment so that adjustments are made with the second revision of the validators, it can be used fit for use.

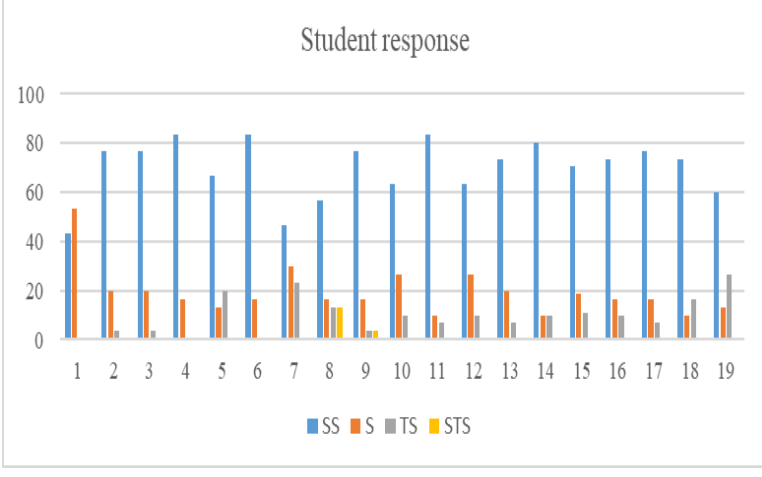

Figure 7. Student Response

\section{Mathematics Examination Completion}

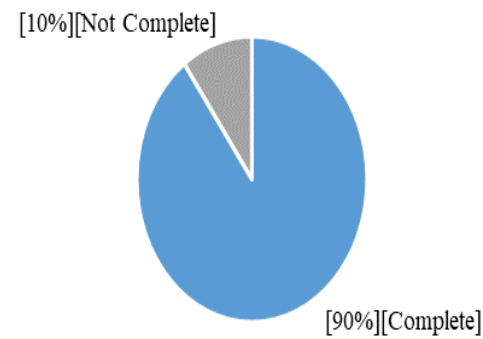

Figure 8. Mathematics Examination Completion

There is 28 students' learning completeness with a total of 30 students. So, the average value is 93.3. If the percentage of student completeness reaches 93.3, which is in the completeness category> 80, then the effectiveness of the Android-based Computer Based Test (CBT) is in the "Very Good" category. Based on the mid-semester tests of mathematics conducted by 30 grade IX students, the average score achieved was 78 . In contrast, the exams results using the Computer Based Test (CBT) carried out by grade IX students obtained an average score of 87.16. The researcher saw an increase or comparison of test scores when students used and did not use the Computer Based Test (CBT), where student test scores increased when using the Computer Based Test (CBT).

\section{Discussion}

The Computer Based Test (CBT) model is designed to be simple, practical and effective so that students can use it. The Computer Based Test (CBT) model is very practical so it can be used by students (Mastroleo et al., 2020; Novrianti, 2014). The research results include the development of the Computer Based Test (CBT) model, validation of material experts and media experts on the Computer Based Test (CBT) model, the results of field trials, and analysis of the practicality and effectiveness of the developed Computer Based Test (CBT) model. a test can be said to be good if it meets five requirements, namely a valid test (validity), high reliability, objectivity, practicality (practicability), and economical (Bolls \& Castell, 2013; Hermes et al., 2019). The basis of evaluation must meet the criteria of validity, reliability and usability (Papamitsiou \& Economides, 2017; Prisacari \& Danielson, 2017). Computer-Based Tests (CBT) are computer-assisted evaluation systems that aim to help teachers evaluate student learning outcomes, scoring, test implementation, and the efficiency of their performance (Chua, 2012; Chua \& Don, 2013). The use of CBT in implementing the evaluation can provide thinking stimulation to students, both from understanding theory and practice. It is more accurate in scoring and minimizes the possibility of errors in both measuring factors, evaluator factors, and student factors (Hill et al., 2019; Mastroleo et al., 2020; Valle et al., 2019). CBT product test data shows that CBT is feasible as a product to help teachers, especially students in general, carry out evaluations in the form of tests more easily (Lia M. Daniels \& Gierl, 2017; Novrianti, 2014). The results of learning evaluation using Computer Based Test (CBT) 
positively impact educators and students. CBT provides several advantages over implementing tests with the paper and pencil test model (Lia M. Daniels \& Gierl, 2017). It includes an automatic scoring system and reduces the burden on respondents or test takers because it is younger to work on questions in a computer-based test than a paper-pencil test.

Student test scores increased when using the Computer Based Test (CBT). Computer Based Test (CBT) products are expected to help solve problems when the evaluation is carried out as an evaluation medium (Bolls \& Castell, 2013; Hermes et al., 2019; Mastroleo et al., 2020). Through this CBT, it is hoped that the assessment will be better and by the common objectives. The results of other studies also conclude that computer-based exams have advantages when compared to paper-based exams, including special assessment and reporting of test results, better test safety, and efficiency (Wang, Jiao, Young, Brooks, \& Olson, 2018). In contrast to the above research results, research conducted by Seoul National University, South Korea, shows that computer-based exams are comparable to paper-based examinations in testing language skills (Choi, Kim, \& Boo, 2013). They conducted a survey to assess whether a test item measuring related constructs via CBT could produce a relatively similar score to the exam's paper-based form. Exam scores presented immediately had significant positive effects on relief, pride, and hope and negative effects on anxiety and shame even after controlling for the corresponding emotion at the end of the exam (L. M. Daniels \& Gierl, 2017).

\section{CONCLUSION}

The level of validity of the learning outcomes assessment instrument using the Computer Based Test (CBT) got a very good category, meaning that the learning outcomes assessment instrument using the Computer Based Test (CBT) was valid. The level of practicality in assessing learning outcomes using the Computer Based Test (CBT) based on teacher and student questionnaire responses is practical. The results of the learning evaluation using the Computer Based Test (CBT) have a positive impact on educators and students.

\section{REFERENCES}

Abidah, A., Hidaayatullaah, H. N., Simamora, R. M., Fehabutar, D., \& Mutakinati, L. (2020). The Impact of Covid-19 to Indonesian Education and Its Relation to the Philosophy of "Merdeka Belajar." Studies in Philosophy of Science and Education, 1(1), 38-49. ttps://doi.org/10.46627/sipose.v1i1.9.

Alessi, S. M., \& Trollip, S. R. (2001). Multimedia For Learning: Methods And Development. European Jurnal of Education Studies, 1(1).

Ayo, C. K., Akinyemi, I. O., Adebiyi, A. A., \& Ekong, U. O. (2017). The Prospects of E-Examination Implementation in Nigeria. Turkish Online Journal of Distance Education, 8(4).

Bergdahl, N., Nouri, J., \& Fors, U. (2020). Disengagement, engagement and digital skills in technologyenhanced learning. Education and Information Technologies, 25(2), 957-983. https://doi.org/10.1007/s10639-019-09998-w.

Bolls, J., \& Castell, S. (2013). Computer based testing. Computer Law \& Security Review, 29(4). https://doi.org/10.1016/j.clsr.2013.05.012.

Cecep, Mutaqin, \& Pamungkas. (2019). Pengembangan Modul Quick Math Berbasis Mobile Learning sebagai Penunjang Pembelajaran Matematika di SMA. Prisma Sains: Jurnal Pengkajian Ilmu Dan Pembelajaran Matematika Dan IPA IKIP Mataram, 7(2). https://doi.org/10.33394/j-ps.v0i0.1761.

Chen, C.-H., \& Tsai, C.-C. (2021). In-service teachers' conceptions of mobile technology-integrated instruction: Tendency towards student-centered learning. Computers \& Education, 170(1). https://doi.org/10.1016/j.compedu.2021.104224.

Choi, I.-C., Kim, K. S., \& Boo, J. (2013). Comparability of a paper-based language test and a computer-based language test. Language Testing, 20(3). https://doi.org/10.1191/02655322031t258oa.

Chua, Y. P. (2012). Effects of computer-based testing on test performance and testing motivation. Computers in Human Behavior, 28(5). https://doi.org/10.1016/j.chb.2012.03.020.

Chua, Y. P., \& Don, Z. M. (2013). Effects of computer-based educational achievement test on test performance and test takers' motivation. Computers in Human Behavior, 29(5). https://doi.org/10.1016/j.chb.2013.03.008.

Daniels, L. M., \& Gierl, M. J. (2017). The impact of immediate test score reporting on university students' achievement emotions in the context of computer-based multiple-choice exams. Learning and Instruction, 52. https://doi.org/10.1016/j.learninstruc.2017.04.001.

Daniels, Lia M., \& Gierl, M. J. (2017). The impact of immediate test score reporting on university students' achievement emotions in the context of computer-based multiple-choice exams. Learning and Instruction, 5(2). https://doi.org/10.1016/j.learninstruc.2017.04.001. 
Devraj, R., Colyott, L., \& Cain, J. (2021). Design and evaluation of a mobile serious game application to supplement instruction. Currents in Pharmacy Teaching and Learning, 13(9). https://doi.org/10.1016/j.cptl.2021.06.032.

Handayani, D., Elvinawati, E., Isnaeni, I., \& Alperi, M. (2021). Development Of Guided Discovery Based Electronic Module For Chemical Lessons In Redox Reaction Materials. International Journal of Interactive Mobile Technologies (IJIM), 15(07), 94. https://doi.org/10.3991/ijim.v15i07.21559.

Hermes, M., Albers, F., Böhnke, J. R., \& Huelmann, G. (2019). Measurement and structural invariance of cognitive ability tests after computer-based training. Computers in Human Behavior, 93. https://doi.org/10.1016/j.chb.2018.11.040.

Hill, A., Horswill, M. S., Whiting, J., \& Watson, M. O. (2019). Computer-based hazard perception test scores are associated with the frequency of heavy braking in everyday driving. Accident Analysis \& Prevention, 122. https://doi.org/10.1016/j.aap.2018.08.030.

Intania, E. V. (2020). The role of character education in learning during the COVID-19 pandemic Peran pendidikan karakter dalam pembelajaran selama pandemi. Jurnal Penelitian Ilmu Pendidikan, 13(2), 129-136.

Irni, Sumarni, \& Saraswati. (2017). Pengembangan Media Pembelajaran Mobile Learning Berbasis Android. Jurnal Penelitian \& Pengembangan Pendidikan Fisika, 3(1), 59. https://doi.org/10.21009/jrpk.072.10.

Jogezai, N. A., Baloch, F. A., Jaffar, M., Shah, T., Khilji, G. K., \& Bashir, S. (2021). Teachers' Attitudes Towards Social Media (SM) Use in Online Learning Amid The COVID-19 Pandemic: The Effects of SM Use by Teachers and Religious Scholars During Physical Distancing. Journal Heliyon, 7(4), 1-9. https://doi.org/10.1016/j.heliyon.2021.e06781.

Kim, M., Lee, H., \& Kwak, J. (2020). The changing patterns of China's international standardization in ICT under techno-nationalism: A reflection through 5G standardization. International Journal of Information Management, 54. https://doi.org/10.1016/j.ijinfomgt.2020.102145.

Kristinawati, E., Susilo, H., \& Gofur, A. (2018). ICT Based-Problem Based Learning on Students' Cognitive Learning Outcomes. Jurnal Pendidikan Sains, 6(2), 38-42. http://dx.doi.org/10.17977/jps.v6i2.11683.

Liu, C., He, J., Ding, C., Fan, X., Hwang, G.-J., \& Zhang, Y. (2021). Self-oriented learning perfectionism and English learning burnout among EFL learners using mobile applications: The mediating roles of English learning anxiety and grit. Learning and Individual Differences, 88. https://doi.org/10.1016/j.lindif.2021.102011.

Liu, Q., Huang, J., \& Zhou, Z. (2020). Self-expansion via smartphone and smartphone addiction tendency among adolescents: A moderated mediation model. Children and Youth Services Review, 119(June), 105590. https://doi.org/10.1016/j.childyouth.2020.105590.

Mastroleo, N. R., Humm, L., Williams, C. M., \& Kiluk, B. D. (2020). Initial testing of a computer-based simulation training module to support clinicians' acquisition of CBT skills for substance use disorder treatment. Journal of Substance Abuse Treatment, 114. https://doi.org/10.1016/j.jsat.2020.108014.

Novrianti, N. (2014). Pengembangan Computer Based Testing (CBT) Sebagai Alternatif Teknik Penilaian Hasil Belajar. Lentera Pendidikan: Jurnal Ilmu Tarbiyah Dan Keguruan, 17(1). https://doi.org/10.24252/lp.2014v17n1a3.

Papamitsiou, Z., \& Economides, A. A. (2017). Exhibiting achievement behavior during computer-based testing: What temporal trace data and personality traits tell us? Computers in Human Behavior, 75. https://doi.org/10.1016/j.chb.2017.05.036.

Park, K.-B., Choi, S. H., Kim, M., \& Lee, J. Y. (2020). Deep learning-based mobile augmented reality for task assistance using 3D spatial mapping and snapshot-based RGB-D data. Computers \& Industrial Engineering, 146. https://doi.org/10.1016/j.cie.2020.106585.

Peralbo-Uzquiano, M., Fernández-Abella, R., Durán-Bouza, M., José-Manuel Cotos-YáñezBrenlla-Blanco, J.-C., \& Brenlla-Blanco, J.-C. (2020). Evaluation of the effects of a virtual intervention programme on cognitive flexibility, inhibitory control and basic math skills in childhood education. Computers \& Education, 159. https://doi.org/10.1016/j.compedu.2020.104006.

Prisacari, A. A., \& Danielson, J. (2017). Computer-based versus paper-based testing: Investigating testing mode with cognitive load and scratch paper use. Computers in Human Behavior, 77. https://doi.org/10.1016/j.chb.2017.07.044.

Rorita, M., Ulfa, S., \& Wedi, A. (2018). Pengembangan multimedia interaktif berbasis mobile learning pokok bahasan perkembangan teori atom mata pelajaran kimia kelas x sma panjura malang. JINOTEP (Jurnal Inovasi Dan Teknologi Pembelajaran) Kajian Dan Riset Dalam Teknologi Pembelajaran, 4(2). https://doi.org/10.17977/um031v4i22018p070.

Sari, I., Sinaga, P., Hernani, \& Solfarina. (2020). Chemistry Learning via Distance Learning during the Covid-19 Pandemic. TADRIS (Journal of Education and Teacher Training), 5(1). https://doi.org/10.24042/tadris.v5i1.6346. 
Sari, Sinaga, Hernani, \& Solfarina. (2020). Chemistry Learning via Distance Learning during the Covid-19 Pandemic. TADRIS (Journal of Education and Teacher Training), 5(1). https://doi.org/10.24042/tadris.v5i1.6346.

Seo, D. G., \& De Jong, G. (2015). Comparability of Online- and Paper-Based Tests in a Statewide Assessment Program: Using Propensity Score Matching. Journal of Educational Computing Research, 52(1). https://doi.org/10.1177/0735633114568856.

Shohel, M. M. C., \& Kirkwood, A. (2012). Using technology for enhancing teaching and learning in Bangladesh: Challenges and consequences. Learning, Media and Technology, 37(4), 414-428. https://doi.org/10.1080/17439884.2012.671177.

Siddiq, F., Hatlevik, O. E., Olsen, R. V., Throndsen, I., \& Scherer, R. (2019). Taking a future perspective by learning from the past - A systematic review of assessment instruments that aim to measure primary and secondary school students' ICT literacy. Educational Research Review, 16. https://doi.org/10.1016/j.edurev.2016.05.002.

Sophonhiranrak, S. (2021). Features, barriers, and influencing factors of mobile learning in higher education: A systematic review. Heliyon, 7(4). https://doi.org/10.1016/j.heliyon.2021.e06696.

Sunismi. (2015). Developing Guided Discovery Learning Materials Using Mathematics Mobile Learning Application As An Alternative Media For The Students Calculus II. Cakrawala Pendidikan, 34(3), 334-346. https://doi.org/10.21831/cp.v3i3.7340.

Suryanda, A., Sartono, N., \& Sa'diyah, H. (2019). Developing smartphone-based laboratory manual as a learning media. Journal of Physics: Conference Series, 402. https://doi.org/10.1088/1742-6596/1402/7/077077.

Valle, S. C., Støen, R., Sæther, R., \& Sæther, R. (2019). Test-retest reliability of computer-based video analysis of general movements in healthy term-born infants. Early Human Development, 91(10). https://doi.org/10.1016/j.earlhumdev.2015.07.001.

Wang, S., Jiao, H., Young, M. J., Brooks, T., \& Olson, J. (2018). Comparability of Computer-Based and Paperand-Pencil Testing in K-12 Reading Assessments: A Meta-Analysis of Testing Mode Effects. Educational and Psychological Measurement, 68(1). https://doi.org/10.1177/0013164407305592. 